\title{
Course of lipaemia retinalis in acquired generalised lipodystrophy
}

\author{
Ashish Markan (1) , Ramandeep Singh
}

Ophthalmology, Post Graduate Institute of Medical Education and Research, Chandigarh, India

\section{Correspondence to} Dr Ramandeep Singh; mank0095@yahoo.com

Accepted 12 April 2021

\section{DESCRIPTION}

Acquired generalised lipodystrophy is a rare skin disorder characterised by severe fat loss in large areas of the body especially the face, arms and legs. This is associated with ectopic fat deposition, leptin deficiency and metabolic abnormalities like insulin resistance, hypertriglyceridaemia, high low density lipoproteins (LDL) and low high density lipoproteins (HDL) levels. ${ }^{1}$ It is an extremely rare disease with over 100 cases reported so far in literature. Lipaemia retinalis refers to abnormal deposition to TG in retinal vessels and entire fundus due to underlying high serum triglycerides (TG) levels. ${ }^{2}$ This condition is usually associated with high TG levels $>1000 \mathrm{mg} / \mathrm{dL}^{3}$ Abnormal deposition of TG produces a salmon-coloured fundus associated with creamish discolouration of retinal arteries and veins in the advanced stages. The disease usually begins in the periphery and progresses towards the centre as the TG levels increase. Lipaemia retinalis is usually asymptomatic and does not affect vision until associated with vascular occlusion. ${ }^{4}$ We report a course of a rare ocular manifestation of a very rarely reported systemic disease.

A 45-year-old woman diagnosed with acquired generalised lipodystrophy was referred to us for fundus evaluation. Blood triglyceride and cholesterol levels were more than $10000 \mathrm{mg} / \mathrm{dL}$ and 1050 $\mathrm{mg} / \mathrm{dL}$, respectively, at the time of presentation. Best-corrected visual acuity in the right eye (OD) was $6 / 18$, and 6/12 in the left eye (OS). Anterior segment evaluation revealed dense senile cataract in both the eyes $(\mathrm{OD}>\mathrm{OS})$. Fundus examination showed presence of salmon coloured fundus with whitening of retinal arteries, and veins suggestive of lipaemia retinalis in both the eyes $(\mathrm{OU})$ (figure $1 \mathrm{~A}$ shows lipaemia retinalis in the OS, arteries marked
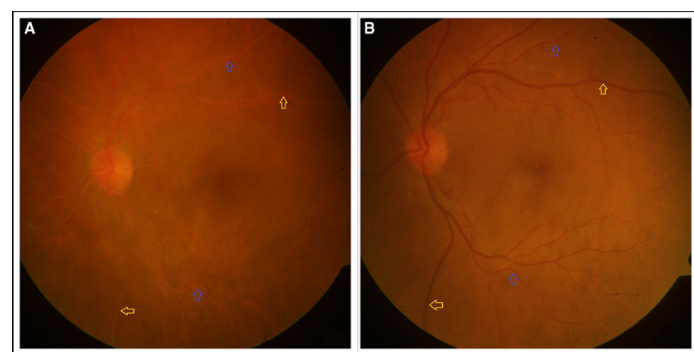

Figure 1 (A) shows salmon-coloured fundus with whitening of retinal vessels suggestive of lipaemia retinalis. (B) shows normal fundus glow with resolution of whitening of retinal vessles.

\section{Learning points}

- Routine fundus evaluation is warranted in patients with lipodystrophy syndromes.

- The clinical ocular findings of lipaemia retinalis should quickly resolve, once the triglyceride levels return to normal.

in blue and veins marked in yellow). Fundus images of the OD were hazy due to presence of dense cataract, and are thus not shown. Loss of vision in OU was attributed to the presence of cataract in both the eyes.

Aggressive treatment with lipid-lowering drugs lead to lowering of triglyceride, and cholesterol levels to $1416 \mathrm{mg} / \mathrm{dL}$ and $318 \mathrm{mg} / \mathrm{dL}$, respectively, at 6 months of follow-up. Fundus examination showed complete resolution of lipaemia retinalis in OU (figure 1B shows resolution in OS).

This report highlights the association of very rare ocular condition with acquired generalised lipodystrophy. Patients with lipodystrophy disorders should be referred for fundus evaluation to rule out lipaemia retinalis. Though lipaemia retinalis is visually not disabling, timely intervention to control serum TG levels can reverse the disease, and prevent development of any vascular occlusions or retinal ischaemia.

Contributors AM prepared the manuscriot. RS managed the patient and reviewed the manuscript.

Funding The authors have not declared a specific grant for this research from any funding agency in the public, commercial or not-for-profit sectors.

Competing interests None declared.

Patient consent for publication Obtained.

Provenance and peer review Not commissioned; externally peer reviewed.

\section{ORCID iDs}

Ashish Markan http://orcid.org/0000-0003-1454-2655

Ramandeep Singh http://orcid.org/0000-0001-9431-6206

\section{REFERENCES}

1 Garg A. Acquired and inherited lipodystrophies. N Eng/ J Med 2004:350:1220-34.

2 Gopal L, Sunder KS, Rao SK, et al. Hyperlipidemia in a poorly controlled diabetic presenting with lipemic aqueous and lipemia retinalis. Retina 2004;24:312-5.

3 Thomas PK, Smith EB. Ocular manifestations in idiopathic hyperlipaemia and xanthomatosis. Br J Ophthalmol 1958;42:501-6.

4 Nagra PK, Ho AC, Dugan JD. Lipemia retinalis associated with branch retinal vein occlusion. Am J Ophthalmol 2003:135:539-42. 
Images in...

Copyright 2021 BMJ Publishing Group. All rights reserved. For permission to reuse any of this content visit https://www.bmj.com/company/products-services/rights-and-licensing/permissions/

BMJ Case Report Fellows may re-use this article for personal use and teaching without any further permission.

Become a Fellow of BMJ Case Reports today and you can:

- Submit as many cases as you like

- Enjoy fast sympathetic peer review and rapid publication of accepted articles

Access all the published articles

Re-use any of the published material for personal use and teaching without further permission

Customer Service

If you have any further queries about your subscription, please contact our customer services team on +44 (0) 2071111105 or via email at support@bmj.com.

Visit casereports.bmj.com for more articles like this and to become a Fellow 